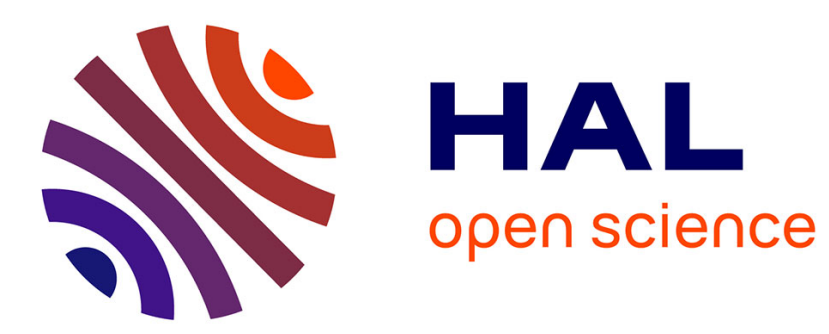

\title{
A fenugreek seed extract selectively reduces spontaneous fat consumption in healthy volunteers
}

Hugues Chevassus, Nathalie Molinier, Françoise Costa, Florence Galtier, Eric

Renard, Pierre Petit

\section{- To cite this version:}

Hugues Chevassus, Nathalie Molinier, Françoise Costa, Florence Galtier, Eric Renard, et al.. A fenugreek seed extract selectively reduces spontaneous fat consumption in healthy volunteers. European Journal of Clinical Pharmacology, 2009, 65 (12), pp.1175-1178. 10.1007/s00228-009-0733-5 . hal00534997

\section{HAL Id: hal-00534997 \\ https://hal.science/hal-00534997}

Submitted on 11 Nov 2010

HAL is a multi-disciplinary open access archive for the deposit and dissemination of scientific research documents, whether they are published or not. The documents may come from teaching and research institutions in France or abroad, or from public or private research centers.
L'archive ouverte pluridisciplinaire HAL, est destinée au dépôt et à la diffusion de documents scientifiques de niveau recherche, publiés ou non, émanant des établissements d'enseignement et de recherche français ou étrangers, des laboratoires publics ou privés. 


\title{
A fenugreek seed extract selectively reduces spontaneous fat consumption in healthy volunteers
}

\author{
Hugues Chevassus • Nathalie Molinier • \\ Françoise Costa $\cdot$ Florence Galtier • Eric Renard • \\ Pierre Petit
}

Received: 18 May 2009 / Accepted: 9 September 2009/Published online: 7 October 2009

(C) Springer-Verlag 2009

\begin{abstract}
Purpose Fenugreek seeds (Trigonella foenum-graecum L.) are an old herbal remedy used to treat metabolic and nutritive dysfunctions. They have been shown to modulate feeding behaviour in animals, but strong clinical data are lacking. The aim of this study was to investigate the effects of a repeated administration of a fenugreek seed extract on energy intake and eating behaviour in healthy human volunteers.

Methods Twelve healthy male volunteers completed a double-blind randomized placebo-controlled three-period cross-over trial of two different doses of a fenugreek seed
\end{abstract}

H. Chevassus $\cdot$ N. Molinier $\cdot$ F. Costa $\cdot$ F. Galtier $\cdot$ P. Petit CHRU Montpellier, Centre d'Investigation Clinique, Montpellier, France

H. Chevassus $\cdot$ N. Molinier $\cdot$ F. Costa $\cdot$ F. Galtier $\cdot$ P. Petit INSERM, CIC 0001,

Montpellier, France

E. Renard

CHRU Montpellier, Service des Maladies Endocriniennes, Montpellier, France

F. Galtier $\cdot$ E. Renard $\cdot$ P. Petit

Université Montpellier I and CNRS UMR 5232,

Centre de Pharmacologie et Innovation dans le Diabète,

Montpellier, France

H. Chevassus ( $\square)$

Centre d'Investigation Clinique INSERM-CHU,

Hôpital Saint-Eloi,

80 avenue Augustin Fliche,

34295 Montpellier Cedex 5, France

e-mail: h-chevassus@chru-montpellier.fr

H. Chevassus

Université Montpellier I and CNRS UMR 5232,

Centre de Pharmacologie et Innovation dans le Diabète,

Montpellier, France extract (588 and $1176 \mathrm{mg}$ ). The three 14-day treatment periods were separated by a 14-day washout period. The main endpoints were energy intake, assessed in volunteers under normal ambulatory and free-living conditions by a 3day detailed dietary record and during a meal test, weight, fasting glucose level, insulin and lipid profile, visual analogue scale scores of appetite/satiety and blood glucose and insulin levels measured repeatedly after a standardized breakfast.

Results Daily fat consumption was significantly decreased by the higher dose of fenugreek seed extract [3.73 vs. $4.51 \mathrm{MJ}_{\mathrm{day}^{-1}},-17.3 \%$ vs. placebo, $95 \%$ confidence interval (CI) -1.51 to $-0.05, n=12, P=0.038]$. This specific reduction tended to lower the total energy intake (9.97 vs. 11.29 $\mathrm{MJ}_{\text {day }^{-1}},-11.7 \%$ vs. placebo, $95 \% \mathrm{CI}-2.91$ to $0.26, n=12, P=0.094)$. No significant effect was observed on the other nutrients or other endpoints.

Conclusions The repeated administration of a fenugreek seed extract specifically decreases dietary fat consumption in humans which, given the traditional use of the plant, constitutes a novel result.

Keywords Eating behaviour - Energy intake $\cdot$ Fat .

Fenugreek seed $\cdot$ Healthy volunteers $\cdot$ Human

\section{Introduction}

Fenugreek (Trigonella foenum-graecum L.) is an herbaceous annual plant from the family of Leguminosae, cultivated in Mediterranean countries and India. Its seeds have long been known as a herbal remedy for various pathological conditions. A number of pharmacological and clinical studies have shown glucose- and lipid-lowering properties of either the seed itself, seed extracts or purified components (see [1] for review). Traditional fenugreek- 
based preparations are used in humans to stimulate appetite and promote weight gain [2]. We have previously shown that a repeated administration of a hydro-alcoholic fenugreek seed extract to rats enhanced their motivation to eat and consume food, resulting in a slight weight increase [3]. Appetite and food intake were also increased by the repeated administration of a purified steroid saponin fraction from the seed, and was associated with a modified circadian rhythm of feeding behaviour [4]. In contrast, in a safety study using a dietary supplement of fenugreek seeds in animals [5], no effect was observed on food consumption. A more recent study reported that a fenugreek seed extract reduced the body weight gain induced by a high-fat diet in obese mice [6]. To date, however, there has been no report of an effect of fenugreek seeds on food intake or body weight in humans. Given the inconclusiveness of these data, we conducted a clinical trial with the aim of evaluating the effects of a repeated administration of a fenugreek seed extract on eating behaviour and energy intake in healthy human volunteers.

\section{Materials and methods}

\section{Study design}

The study was a double-blind randomized placebocontrolled three-period cross-over trial of two different doses of a fenugreek seed extract, according to a Latin square design. The three 14-day treatment periods were separated by 14-day washouts.

\section{Subjects}

Twelve healthy male volunteers, aged 19-26 years (mean 22 years), were included in this study. All were of normal and stable weight (mean weight $71.6 \mathrm{~kg}$, range 60.5-80.6, mean body mass index $22.5 \mathrm{~kg} \mathrm{~m}^{-2}$, range 20.0-25.0).

\section{Ethical aspects}

This study was approved by the Ethics Committee "Comité de Protection des Personnes Montpellier-Saint-Eloi" and conducted in accordance with the Helsinki declaration and the ICH guideline for Good Clinical Practice. All the subjects gave written informed consent to participate.

\section{Test compound}

The test compound was a marketed dry hydro-alcoholic seed extract administered three times daily as oral coated tablets in one of two daily doses: a total daily dose of $588 \mathrm{mg}$ (approximately $8 \mathrm{mg} \mathrm{kg}^{-1}$ ), which is the daily dose of the extract commonly prescribed in humans, or a double dose $1176 \mathrm{mg}$ (approximately $16 \mathrm{mg} \mathrm{kg}^{-1}$ ). These doses fall within the range of active doses used in a previous animal study testing the same extract [3] and corresponds to 5$53 \mathrm{mg} \mathrm{kg}^{-1}$ human equivalent doses. The extract contains diosgenine, steroid saponins, $1.38 \%$ trigonelline and $1.50 \%$ 4-hydroxyisoleucine, as characterized by thin-layer chromatography and high-performance liquid chromatography. Placebo tablets were manufactured using the same excipients, the same process and the same packaging as those used for the active tablets, thereby rendering them indistinguishable from the active tablets. The similarity between the seed extract and the placebo tablets was verified on five criteria (aspect, size, weight, colour and smell).

Investigations

On day 0 and day 14 of each period, the participants came to the centre in a fasting condition. Body weight was recorded with the volunteers dressed in only underclothing and after having urinated; the same balance, accurate to $\pm 0.1 \mathrm{~g}$, was used for all measurements. Blood was drawn for determination of the plasma lipid profile. The treatment was taken ambulatory from day 1 to day 14 ; from day 11 to day 13 , the subjects completed a detailed dietary record under free-living conditions. After validation by a dietician, nutrient analysis was performed using IDI software. At 8:00 a.m. on day 14, the time-course of plasma glucose and serum insulin concentrations and the subjective scores of appetite and satiety using visual analogue scales $[7,8]$ were evaluated before and every 30 min after consumption of a standardized breakfast (750 kcal, $13 \%$ proteins, $35 \%$ fat and $52 \%$ carbohydrates). At 12:30 p.m., a test meal of standardized composition was given ad libitum to evaluate the total energy intake and the type of nutrients preferentially consumed.

\section{Analytical methods}

Plasma glucose was assayed by the glucose oxidase method. Serum insulin was measured by a radioimmunoassay (BI-INSULIN RMA; CIS Bio-international, Gif-sur-Yvette, France). Serum triglycerides, total cholesterol and high-density lipoprotein (HDL)-cholesterol were assayed with an enzymatic method (lipase/glycerokinase, cholesterol oxidase and cholesterol oxidase after separation, respectively).

Data analysis and statistics

Results are expressed as the mean \pm standard error of the mean (SEM). The time-courses of postprandial glucose and insulin concentrations, and appetite and satiety scores were integrated in areas under the curves, calculated, including 


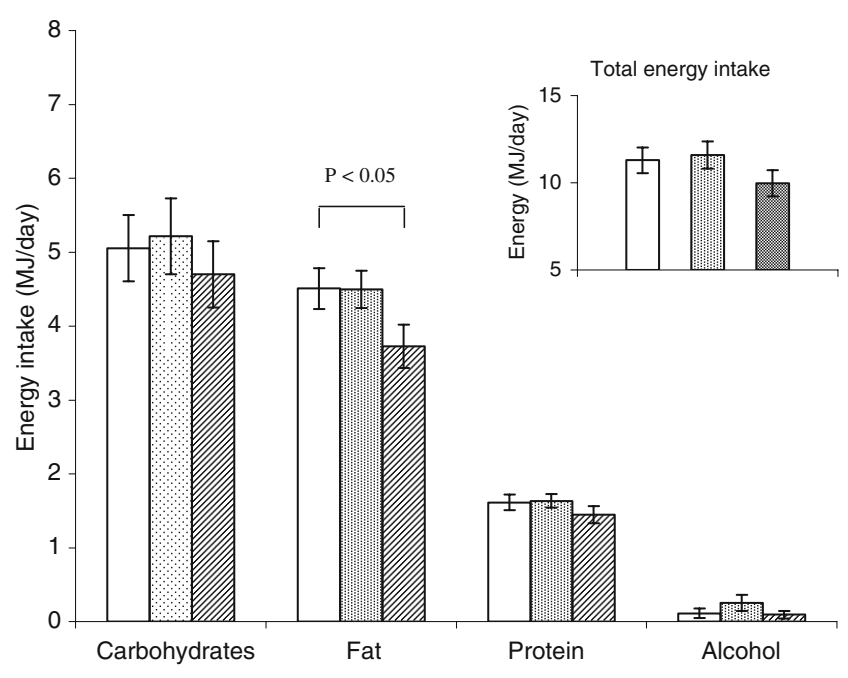

Fig. 1 Energy intake (MJ day ${ }^{-1}$ ) recorded by subjects under freeliving conditions during the last 3 days of the 14-day treatment period: placebo (white bars), fenugreek seed extract $588 \mathrm{mg} \mathrm{day}^{-1}$ (dotted bars), fenugreek seed extract $1176 \mathrm{mg} \mathrm{day}^{-1}$ (striped bars)

the baseline, by the trapezoidal rule. Means were compared using repeated-measures analysis of variance. 95\% Confidence intervals for the differences $(95 \% \mathrm{CI})$ are given where necessary. Post hoc analyses were performed using the paired $t$ test. Calculations and statistical analysis were performed using the Systat ver. 6.0 software for Windows from SPSS (SPSS, Chicago, IL).

\section{Results}

As shown in Fig. 1, a significant decrease in daily fat consumption, as measured by the 3-day record, was observed in the subjects treated by the higher dose of the fenugreek seed extract (3.73 vs. $4.51 \mathrm{MJ}$ day $^{-1},-17.3 \%$ vs. placebo, $95 \% \mathrm{CI}-1.51$ to $-0.05, n=12, P=0.038$ ). This specific reduction tended to lower the total energy intake (9.97 vs. $11.29 \mathrm{MJ}$ day $^{-1},-11.7 \%$ vs. placebo, $95 \%$ CI -2.91 to $0.26, n=12, P=0.094)$. Fasting data on weight, lipid profile, plasma glucose and serum insulin are summarized in Table 1. No significant alterations were observed for other nutrients, weight, lipid profile or the time-course of serum insulin and plasma glucose concentrations after the standardized breakfast. The scores of appetite and satiety and the food consumed during the meal test were unchanged.

Among the nine non-serious adverse events reported during the three treatment periods, only three may have been related to the treatment: one case of abdominal pain and two cases of a specific urine smell.

\section{Discussion}

The results of this study reveal for the first time that a 14day treatment with a fenugreek seed extract reduces daily fat consumption in healthy, normal weight volunteers, with a tendency towards a decrease in total energy intake. We also show that the fenugreek seed extract does not increase appetite or food consumption. This latter result differs from the traditional use of fenugreek-based preparations for appetite stimulation and weight gain [2]. It also contrasts with our previous observations of enhanced food consumption in animals administered the hydro-alcoholic crude extract or a purified steroid saponin fraction [3, 4].

The effect of fenugreek seed extract on fat consumption is specific, without any significant change in the intake of other nutrients and without any alteration of appetite or palatability. It was observed only under free-living conditions, based on a record of all food eaten during a 3-day period, but was not found in the standardized meal test situation. This difference in results is likely related to the lack of sensitivity of a single meal test.

Such a specific effect has already been observed in pharmacological studies undertaken in rats by activation of the hypothalamic serotonin pathway [9], and in human after a methylphenidate challenge activating the brain dopamine pathway by blocking its reuptake [10].

Table 1 Summary of fasting data of weight, lipid profile, plasma glucose and serum insulin before and after each treatment period

\begin{tabular}{|c|c|c|c|c|c|c|}
\hline \multirow[t]{2}{*}{ Parameters } & \multicolumn{2}{|l|}{ Placebo } & \multicolumn{2}{|c|}{$\begin{array}{l}\text { Fenugreek seed extract: } 588 \mathrm{mg} \\
\text { day }^{-1}\end{array}$} & \multicolumn{2}{|c|}{$\begin{array}{l}\text { Fenugreek seed extract: } 1176 \mathrm{mg} \\
\text { day }^{-1}\end{array}$} \\
\hline & $\begin{array}{l}\text { Baseline } \\
(n=12)\end{array}$ & $\begin{array}{l}\text { Post- treatment } \\
(n=12)\end{array}$ & $\begin{array}{l}\text { Baseline } \\
(n=12)\end{array}$ & $\begin{array}{l}\text { Post- treatment } \\
(n=12)\end{array}$ & $\begin{array}{l}\text { Baseline } \\
(n=12)\end{array}$ & $\begin{array}{l}\text { Post- treatment } \\
(n=12)\end{array}$ \\
\hline Weight $(\mathrm{kg})$ & $72.5 \pm 2.0$ & $72.4 \pm 2.0$ & $72.2 \pm 1.9$ & $72.2 \pm 2.0$ & $72.1 \pm 1.9$ & $72.1 \pm 2.0$ \\
\hline Triglycerides $\left(\mathrm{mmol} \mathrm{l}^{-1}\right)$ & $1.0 \pm 0.1$ & $0.8 \pm 0.1$ & $0.9 \pm 0.1$ & $0.9 \pm 0.1$ & $1.1 \pm 0.2$ & $0.8 \pm 0.1$ \\
\hline Total cholesterol $\left(\mathrm{mmol} \mathrm{l}^{-1}\right)$ & $4.9 \pm 0.2$ & $4.5 \pm 0.2$ & $4.7 \pm 0.2$ & $4.4 \pm 0.2$ & $4.8 \pm 0.2$ & $4.4 \pm 0.2$ \\
\hline High-density lipoprotein-cholesterol ( $\left.\mathrm{mmol} \mathrm{1}^{-1}\right)$ & $1.2 \pm 0.1$ & $1.1 \pm 0.1$ & $1.2 \pm 0.1$ & $1.1 \pm 0.0$ & $1.1 \pm 0.0$ & $1.1 \pm 0.1$ \\
\hline Fasting plasma glucose $\left(\mathrm{mmol} \mathrm{l}^{-1}\right)$ & - & $5.0 \pm 0.1$ & - & $4.8 \pm 0.1$ & - & $4.8 \pm 0.1$ \\
\hline Fasting serum insulin $\left(\mathrm{mU}^{-1}\right)$ & - & $9.7 \pm 1.0$ & - & $8.6 \pm 1.4$ & - & $7.3 \pm 0.6$ \\
\hline
\end{tabular}


The reduction in fat intake observed in our study is in accordance with the recently reported reduction in body weight gain induced by a high-fat diet in obese mice [6]. We were unable to detect any weight modification in our volunteers, which may be explained by the healthy status of the subjects and the short duration of the treatment. It is also worth noting that no significant change in body weight was observed by Sharma et al. [11] in a clinical study in which they evaluated the safety of fenugreek seeds consumed by diabetic patients; however, their study was not designed to assess eating behaviour or weight modifications. Nevertheless, based on these results, it can be suggested that the administration of a fenugreek seed extract may improve the metabolic status and favour a weight reduction in the long term, particularly in some subgroups of overweight or obese patients for whom a lowfat diet is recommended.

The treatment with the fenugreek seed extract did not modify the lipid profile or the glucose tolerance of our volunteers. This result may also be explained by the healthy status of the subjects and the short duration of the treatment.

\section{Conclusion}

Based on the results reported here, the repeated administration of a fenugreek seed extract specifically decreases dietary fat consumption in humans which, given the traditional use of the plant, constitutes a novel result that requires further confirmation. The fenugreek seed's component(s) involved and the mechanism(s) of this effect remain to be elucidated.

Acknowledgements This study was sponsored by the University Hospital of Montpellier (UF7599) with the financial support of Laboratoires Legras (Cachan, France). We specially thank B BoriesAzeau (administrative assistant) for her extensive effort in recruiting volunteers and managing the study. This study was also successfully carried out thanks to the expert scientific, medical, biological and logistic assistance of R. Blanc, A. Bonardet, F. Michel, C. Montaudié, M.C. Picot and A.M. Puech-Cathala.

\section{References}

1. Sauvaire Y, Petit P, Baissac Y, Ribes G (2000) Chemistry and pharmacology of fenugreek. In: Mazza G, Oomah BD (eds) Herbs, botanicals and teas. Technomic, Lancaster, pp 107-129

2. Rguibi M, Belahsen R (2006) Body size preferences and sociocultural influences on attitudes towards obesity among Moroccan Sahraoui women. Body Image 3:395-400

3. Petit P, Sauvaire Y, Ponsin G, Manteghetti M, Fave A, Ribes G (1993) Effects of a fenugreek seed extract on feeding behaviour in the rat: metabolic-endocrine correlates. Pharmacol Biochem Behav 45:369-374

4. Petit PR, Sauvaire YD, Hillaire-Buys DM, Leconte OM, Baissac YG, Ponsin GR, Ribes GR (1995) Steroid saponins from fenugreek seeds: extraction, purification, and pharmacological investigation on feeding behavior and plasma cholesterol. Steroids 60:674-680

5. Udayasekharan Rao P, Sesikeran B, Srinivasa Rao P, Nadamuni Naidu A, Vikas RV, Ramachandran EP (1996) Short term nutritional and safety evaluation of fenugreek. Nutr Res 16:1495-1505

6. Handa T, Yamaguchi K, Sono Y, Yazawa K (2005) Effects of fenugreek seed extract in obese mice fed a high-fat diet. Biosci Biotechnol Biochem 69:1186-1188

7. Hill AJ, Magson LD, Blundell JE (1984) Hunger and palatability: tracking ratings of subjective experience before, during and after the consumption of preferred and less preferred food. Appetite 5:361-371

8. Raben A, Tagliabue A, Astrup A (1995) The reproducibility of subjective appetite scores. Br J Nutr 73:517-530

9. Smith BK, York DA, Bray GA (1999) Activation of hypothalamic serotonin receptors reduced intake of dietary fat and protein but not carbohydrate. Am J Physiol 277:R802-811

10. Goldfield GS, Lorello C, Doucet E (2007) Methylphenidate reduces energy intake and dietary fat intake in adults: a mechanism of reduced reinforcing value of food? Am J Clin Nutr 86:308-315

11. Sharma RD, Sarkar A, Hazra DK, Misra B, Singh JB, Maheshwari BB (1996) Toxicological evaluation of fenugreek seeds: a long term feeding experiment in diabetic patients. Phytotherapy Res 10:519-520 